\title{
IMPLEMENTASI MANAJEMEN MUTU TERPADU DALAM MENINGKATKAN KUALITAS PENDIDIKAN
}

\author{
Fadilla Windryani \\ Universitas Negeri Padang \\ Indonesia \\ E-mail : windriani2408@gmail.com
}

\begin{abstract}
abstrak
Implementation of the Total Quality Management in the Learning Quality Management System in Educational Institutions. This study aimed to analyse the implementation of the Total Quality Management (TQM) in the learning quality management system in educational institutions. This study used a descriptive design. The population consisted of people in the organizational structure of the quality management system and the sample was pusposively selected. The data were collected through interviews and documents and were analysed using the descriptive technique. The findings show that: (1) the TQM has been implemented but it still needs optimizing, (2) it needs support from the heads of relevant units, (3) there are constraints because of work teams that are not optimal and limited time and funds, (4) the strategies to deal with the constraints depend on the condition and situation, and (5) the implementation of the TQM refers to an evaluation and monitoring study and the draft of academic quality assurance documents.
\end{abstract}

Keywords: Implementation, TQM, Learning, Education

\section{PENDAHULUAN}

Upaya peningkatan mutu pendidikan oleh pihak penyelenggara pendidikan dilakukan dengan sangat gencarnya. Strategi pengembangannya antara lain dilakukan dengan menerapkan paradigma baru berupa peningkatan kualitas berkelanjutan di masa mendatang yang dikenal dengan nama Total Quality Management (TQM). TQM berkaitan dengan penciptaan budaya kualitas yang bertujuan agar penyelenggara prndidikan dapat memuaskan konsumen (pihak etiga seperti orang tua siswa) agar mereka mau memasukkan anak mereka ke dalam sekolah tersebut sekaligus didukung oleh struktur organisasi mereka dalam melakukan hal yang diinginkan. Organisasi yang menggunakan TQM berupaya untuk mengadakan perbaikan secara berkelanjutan dalam rangka memenangkan persaingan dalam era global mendatang. Dalam bidang pendidikan TQM tentunya sangat dibutuhkan agar kualitas pendidika ndi sekolah tersebut menjadi lebih baik lagi dari sebelumnya. Pihak penyelenggara pendidiak nseharusnya lebih bisa memperhatikan apa-apa saja yang dibutuhkan oleh pendidiak ndi sekolahnya sehingga dengan demikian akan lebih mudah untuk mencari bagaimana ahgar kebutuhan tersebut dapat terpenuhi. Pemenuhan kebutuhanakan pendidikan akan menjadi lebih mudah saat seorang maanjer atau pimpinan pada suatu organisasi memahami dan mengetahui apa-apa saja yang harus disediakan di dalam organisasinya tersebut. (Zusrony, 2013) 
mengatakan bahwa salah satu usaha yang dapat dilakukan agar kualitas sumber daya manusia disuatu organisasi lebih berkualitas yaitu dengan menerapkan sistem manajemen mutu terpadu (Total Quality Management).

Penerapan manajemen mutu terpadu dalam bidang pendidikan akan mempermudah pencapaian tujuan pendidikan pada suatu instansi pendidikan itu berada. Jadi sudah seharusnya para leader di sekoah harus bekerjasama dalam meningkatkan kualitas pendidikan yang benar-benar baik dan memadai sehingga akan membuat konsumen merasa bahwa apa yang bereka butuhkan memang benar-benar ada dalam instansi tersebut. Dengan begitu akan terciptalah image yang baik di dalam diri masyarakat mengenai kulitas maupun kuantitas dalam suatu instansi tersebut.

\section{Metode Penelitian}

Dalam artikel ini peneliti menggunakan metode studi literatur dengan cara mengumpulkan literatur (bahan-bahan materi) yang bersumber dari buku, jurnal, dan sumber lainnya. Semua bahan yang bersangkutan dengan menulisan artikel ini dikumpulkan kemudian dipelajari dan dipahami oleh peneliti untuk kemudian hasil penelusuran dan menelitian itu dituangkan dalam artikel ini secara sistematis dan kronologis. Hasil-hasil penelitian ini dapat dideskripsikan berdasarkan urutan pencapaian tujuan penelitian.

III. Kajian Teori dan Pembahasan

\section{A. Pengertian TQM}

Ialah suatu sistem manajemen kualitas yang berfokus pada pelanggan demgan meningkatkan semua level karyawa ndalam melakukan peningkatan atau perbaikan yang berkesinambungan yaitu secara terus menerus. Total Quality Management menggunakan strategi data dan komunikasi yang efektif untuk mengintegrasikan kedisiplinan kualitas kedalam budaya dan kegiatan kegiatan organisasi. Pada intinya TQM adalah pendekatan manajemen untuk mencapai keberhasilan jangka panjang melalui kepuasan pelanggan. (Zusrony, 2013) menjelaskan TQM diartikan sebagai perpaduan semua fungsi dari perusahaan ke dalam falsafah holistik yang dibangun berdasarkan konsep kualitas, teamwork, produktivitas serta kepuasan. (Afriansyah, 2019) menyatakan bahwa pengawasan dan evaluasi bertujuan untuk mengontrol agar semua proses berjalan dengan tepat untuk mencapai tujuan karena besarnya kemungkinan terjadi perubahan situasi dan kondisi, sehingga proses dari manajemen harus fleksibel.

(Rusdinal, 2009) mengatakan bahwa dengan mengembangkan budaya organisasi yang teratur disiplin serta menggunakan pendekatan manajemen yang baik itu juga akan menunjang peningkatan kinerja dan kualitas dari sumer daya manusia dalam organisasi tersebut.

B. Prinsip Total Quality Managament

Penerapan prinsip-prinsip TQM pada SMM yang mencakup pemfokusan pada pelanggan, perbaikan pada proses, dan pelibatan 
anggota dalam berbagai kegiatan SMM. Pemfokusan kegiatan ke pelanggan (mahasiswa, dosen, dan staf) sudah dilakukan, tetapi belum optimal. Kondisi yang ada menunjukkan adanya perubahan pelayanan terhadap mahasiswa. Perbaikan proses kegiatan secara terus-menerus, khususnya terkait dengan proses pembelajaran sudah tampak dari meningkatnya kedisiplinan dan komitmen dosen dalam melaksanakan proses perkuliahan (kehadiran dosen, penyusunan RPS, penyelenggaraan evaluasi pembelajaran, presensi kehadiran mahasiswa, sampai pada pengembalian tugas dan hasil ujian mahasiswa). Hal tersebut terkontrol melalui Monev yang dilakukan GPM, UPM, dan BPM. Kegiatan ini dilakukan tiga kali dalam satu semester. Pelibatan anggota organisasi oleh BPM secara menyeluruh belum dilakukan secara optimal. Hal ini ditunjukkan oleh anggota organisasi yang belum sepenuhnya terlibat dalam kegiatan penjaminan mutu dalam suatu universitas. Beberapa perguruan tinggi mengalami kesulitan ketika mengimplementasikan TQM yang disebabkan oleh sistem periodisasi waktu yang kuat Berbagai kendala yang dihadapi perguruan tinggi ketika mengimplementasikan TQM cukup variatif sesuai dengan situasi dan kondisi institusi masing-masing. Semua itu membutuhkan strategi untuk mengatasinya sehingga walaupun ada kendala, TQM nantinya dapat diimplementasikan di bidang pendidikan dengan baik. Hal yang sangat disarankan untuk membangun institusi pendidikan yang baik adalah dengan cara meningkatkan kualitas pendidikan secara terus-menerus, terutama pada pembelajarannya agar para mahasiswa menjadi pemikir yang kritis dan kreatif dalam menghadapi perubahan teknologi yang cepat.

\section{Syarat Implementasi TQM}

1. komitmen yang tinggi dari manajemen puncak Artinya agar mamajemen mutu terpadu ini dapat dilaksankan harus adanya komitmen yan gtinggi dari pihak leader organisasi tersebut karena setiap keputusan yang diambil nantinya akan diserahkan pada pihak manajer puncak untuk mempertimbangkana bagaimana arah selanjutnya yang akan diambil

2. mengaloasikan waktu secara penuh untuk TQM

Untk pelaksanaan manajemen mutu terpadu ini selain komitmen yang tinggi diperlukannya pula komitmen waktu yang banyak dariseriap pelaku dalam hal pengembangan mutu dalam suatu organisasi tersebut

3. menyiapkan dana dan mempersiapkan sumber daya manusia yang berkualias

Dana yang dibutuhkan dalam haal peningkatan mutu tentungya tidaklahsedikit oleh karena itu pihak organisasi harus mempertimbangkan pula bagaiman dan darimana dana yang akan dikeluarkan dalam rangka meningkatkan mutu do irganisasi 
khususnya di bidang pedidikan oleh pihak pimpinan

4. memilih koordinator program yang mumpuni

Pemilihan koordinator juga menjadi syarat terlaksananya mutu pendidikan yang tinggi. Pemilihan koordinator henaknya memilih orang orang yang berpengalaman dan memiliki keahlian dalm bidang tersebut agar jika didapati suatu permasalahan dia sudah memiliki rencana bagaimana strategi untuk menghadapi permasalahan tersebut

5. melakukan banchmarking pada perusahaan lain yang menetapkan TQM

Artinya perlu jug dilakukan pemantauan terhadap perusahaan lain yang sudah terlebih dahulu menerapkan menejemen mutu terpadu di perusahaannnya.

6. merumuskan nilai (value) visi dan misi dari TQM

Unyuk menerapkan TQM, penetapan visi dan misi juga merupakan salah satu hal yang sangat penting. Tujuannya ialah agar dalam tahap pelaksanaan tujuan perjalanannya bisa lebih terarah.

7. mempersiapkan mental untuk menghadapi berbagai bentuk hambatan

Hambatan dalam sebuh usahah pasti akan teerus ada. Untu kitu setiap pelaku dari TQM harus menyiapkan mental yan gkuat agar jika dalam meaksanakan rencana terdapat problem bisa lebih tenrang menghadapi sehingga penyelesaian masalah pun bisa segera diatasi.
8. Merencanakan mutasi program TQM.

Mutasi ini berfungsi jika rencana yang diawal dirasa kurang tepat sasaran makadiperlukannlah mutasi untuk rencana pengembangan bidang pendidikan yang lebih baik dan terarah.

D. Implementasi Total Quality Management dalam pendidikan

implementasi TQM pada sistem manajemen mutu di institusi pendidikan sudah dijalankan, tetapi belum optimal. Tujuan utama TQM dalam pendidikan adalah meningkatkan mutu pendidikan secara berkelanjutan, terus-menerus, dan terpadu. Pencapaian tujuan dapat diwujudkan menggunakan prinsip-prinsip pemfokusan pada pengguna, peningkatan kualitas pada proses, dan pelibatan semua komponen pendidikan. Sudah abnyak ditemui di bidang pendidika banyak instansi seperti sekolah-sekolah yang menerapkan TQM ini untuk menunjang mutu pendidikan di seklah tersebut. Dengan penerapan Total Quality Management yang baik sekolah tersebut bisa dengan muda mencapai mutu yang ingin dicapai.

\section{KESIMPULAN}

Manajemen mutu terpadu (TQM) adalah suatu sistem manajemen kualitas yang berfokus pada pelanggan dengan meningkatkan semua level karyawan dalam melakukan peningkatan atau perbaikan yang berkesinambungan yaitu secara terus menerusPenerapan TQM dalam bidang pendidiakn dilakukan oleh orang yang ahli pada bidangnya dengan upaya lebih dari pihak pimpinan 
pendidikan agar mutu pendidikan benar-benar terjamin. Baik dari segi kualitas maupun dari segi kuantitasnya. Penerapan manajemen mutu terpadu pada bidang pendidikan dapat menjadi langkah yang bagus untuk sekolah dalam membangun pemikiran positif masyarakat terhadap sekolah tersebut.

\section{Daftar Pustaka}

Afriansyah, H. (2019). MANAJEMEN MUTU TERPADU. 1. https://doi.org/10.17605/OSF.IO/JXCQY

Rusdinal. (2009). BUDAYA ORGANISASI PASCA PENGEMBANGAN DENGAN DUKUNGAN MANAJEMEN BERBASIS SEKOLAH. Pedagogi, 33(2). Retrieved from http://journal.um.ac.id/index.php/ilmupendidikan/article/view/1200

Zusrony, E. (2013). PENGARUH PENERAPAN PERAN TOTAL QUALITY MANAGEMENT TERHADAP KUALITAS SUMBERDAYA MANUSIA. Pedagogi, 17(1), $7 . \quad$ Retrieved from http://journals.ums.ac.id/index.php/benefit/article/viewF ile/1371/927 